\title{
Retrato incompleto de Eudinyr Fraga
}

\author{
Daniela Elyseu Rhinow
}

0 de dezembro de 2001. Um recado na secretária eletrônica me informa do falecimento de Eudinyr Fraga, meu orientador, professor, amigo. Meu pensamento imediato: estamos órfāos. Eu, pelo menos, estava.

Eudinyr foi literalmente o primeiro professor que tive ao ingressar no curso de Artes Cênicas da ECA/USP. Aliás, já tínhamos nos encontrado na prova prática do vestibular, quando ele me sabatinara sobre Rasga Coração, de Vianninha. Logo de saída, impressionou-me sua erudição, que para uma jovem aluna de primeiro ano, provocava uma sensação de ignorância profunda. Mas Eudinyr não se gabava de seu próprio conhecimento. Sabia trechos da Poética de Aristóteles de cor "porque depois de tanto tempo dando aula disso, a gente decora...” A disciplina era História do Teatro I. Ele era também o responsável por Literatura Dramática I, em que tratava do simbolismo no teatro e de movimentos subseqüentes. A nossa turma era composta por calouros de todos os tipos, sedentos de conhecer e fazer teatro. Foi, creio, uma união muito feliz - oito horas semanais unindo a nossa necessidade voraz com a sapiência tranqüila de Eudinyr. No final do semestre, para minha surpresa, ele me presenteou com um livro: uma edição antiga de Tristão e Iseu. Pediume que o lesse durante as férias e que preparas- se um seminário sobre ele para o começo de agosto, quando iniciaríamos os estudos sobre Idade Média. Tratei da incumbência com prazer. O seminário não foi dos melhores, mas Eudinyr fez questão de se reunir comigo e apontar os erros e acertos do meu trabalho.

Quando se formou em Direito, na década de 1950, Eudinyr fazia parte do grupo de teatro de Lotte Sievers. Como afirma Sábato Magaldi, "era um grupo sério, que fazia teatro amador fora dos moldes tradicionais". Apaixonada por teatro e visando difundir autores alemães no Brasil, Sievers buscava realizar bons espetáculos, contratando inclusive diretores profissionais (Antunes Filho e Sérgio Britto chegaram a dirigir peças ali).

Segundo outra orientanda de Eudinyr, Elisabeth Azevedo, que pesquisou a história do grupo de Lotte Sievers, Eudinyr contava várias histórias desse período. "O grupo de Dona Lotte era singular: apesar de amador, dispunha de dinheiro e primava pela qualidade. Pessoas como Odavlas Petti, Córdoba Reis (que faria parte da companhia de Maria Della Costa) e Raul Cortez (sob o nome de Cristiano Machado) chegaram a tomar parte no grupo".

Eudinyr trabalhou como ator em várias peças, entre elas $A$ Calça e Os Ratos, e ajudava na tradução dos textos. Ele ficou no grupo até

Daniela Elyseu Rhinow é doutoranda pelo Departamento de Letras Modernas da FFLCH-USP. 
o seu final, e depois continuou mantendo algumas das amizades ali travadas. Sábato Magaldi, que se tornou um amigo da vida toda, comenta as afinidades que aproximaram estes dois estudiosos do teatro: "Tínhamos muitas semelhanças. Ele era procurador e eu também, de órgãos diferentes que se fundiram no INSS. Até colegas de repartição pública nós fomos. Quanto à universidade, muitas vezes nós íamos juntos, voltávamos juntos, ultimamente éramos quase vizinhos. Lá também nos dávamos muito bem, tínhamos muito em comum, como o horror a reuniōes..."

Eudinyr realmente não era fã de reuniōes. Seu lugar natural era a sala de aula, onde ensinava e deixava os alunos aprenderem, incentivando que lhe tomassem a palavra. Era entusiasta de seminários, que forçavam os estudantes a pesquisar e a estudar, e sempre complementava as apresentações com outros pontos não explorados. Era fácil encontrar a bibliografia de seus cursos, pois ele deixava os livros reservados na biblioteca, para que todos tivessem acesso rápido a eles e pudessem estudar. Como lembra Elisabeth Azevedo: "O Eudinyr se empenhava muito, pois dava aulas com muito prazer e satisfação. Ele sempre gostou da vida de professor, e só tinha aversão à burocracia: nunca quis cargos, posição de chefe, ele não gostava disso, não era o objetivo dele."

Tal desprendimento não o impediu de ser diretor da Escola de Arte Dramática - onde fora aluno - de 1976 a 1978, um período de renovação posterior à união da EAD com a Universidade de São Paulo. Segundo Sábato Magaldi: "Ele foi um dos diretores que haviam sido alunos de Alfredo Mesquita. Acho que Eudinyr apreendeu bem o espírito do Alfredo, de conduzir o curso com seriedade. Ele era um bom discípulo e sua preocupação em manter a Escola funcionando com disciplina foi muito benfazeja para a EAD.”

$\mathrm{Na}$ época de graduação, ele ainda era "o Fraga”. Assim ele era chamado por todos os alunos, que se deliciavam com as suas reminiscências durante as aulas de Teatro Brasileiro I e II.
Apenas os professores se referiam a ele pelo primeiro nome, um privilégio do qual fui gozar somente ao iniciar o mestrado sob sua orientação, em 1996. Não que ele fizesse questão de manter-se distante, nada disso; não gostava de ser chamado de "senhor", preferindo o cotidiano "você".

Considero um privilégio ter sido orientanda de Eudinyr. Ao mesmo tempo em que ele dava a liberdade para o aluno trilhar a pesquisa com os próprios pés, a observação arguta e incansável sempre vinha quando necessário. Some-se a isso a generosidade e certas tiradas que só posso definir como witty, e as reuniōes de orientação - normalmente em seu apartamento, na rua Martim Francisco - tornavam-se sempre fecundas. Elisabeth Azevedo concorda comigo: "O Eudinyr orientador era aquela figura que te guia. Ele me ajudou muito nas minhas leituras, mesmo fora do projeto, para completar minha formação teórica. Ele era muito paciente e disponível."

Grande estudioso, especialmente do teatro nacional, preocupado em ressaltar acertos sem fugir, quando necessário, da crítica contundente (feita com autoridade, não se importando com a notoriedade do criticado), Eudinyr iluminou certos aspectos da vida teatral brasileira em suas obras.

Primeiramente, em seu mestrado, ocupou-se de Qorpo-Santo, autor até então pouco difundido. Demonstrando já o domínio teórico de várias áreas do conhecimento, ele questionou a idéia de que o dramaturgo seria precursor do Teatro do Absurdo, apontando semelhanças do autor gaúcho com o também posterior movimento surrealista.

No doutorado, trilhou outro caminho pouco seguido: o do teatro simbolista no Brasil. Um tema árido e obscuro, revelado com inteligência, em uma obra preocupada não apenas em analisar os autores mais conhecidos do movimento, mas também em pesquisar e encontrar outros exemplos. Quem define os caminhos do Eudinyr pesquisador é Sábato Magaldi: "Ele gostava de aproveitar os aspectos 
pouco explorados, pouco conhecidos. Quando trabalhou com Qorpo-Santo, este ainda não havia quase sido estudado; era semelhante ao próprio Eudinyr pelo lado pouco convencional, pouco comum. Depois ele foi bater em uma coisa difícil que era o Simbolismo, foi a fundo e até descobriu Durval de Moraes, um autor até então desconhecido. Eudinyr tinha muita sensibilidade, não ficava no convencional a respeito de um tema. Sempre queria extrair algo diferente, algo que poderia escapar."

Mas Eudinyr não se furtou a examinar, também, dramaturgos consagrados, como prova sua terceira obra, Nelson Rodrigues Expressionista. Partindo de um elemento específico e, como passamos a perceber, dominante em muitos casos, ele faz uma leitura abrangente da obra do autor. É desse livro que retiro uma citação que creio ser típica de Eudinyr, por sua ironia perspicaz e pela afirmação sem meias palavras. Tratando da relação entre Senhora dos Afogados, de Nelson Rodrigues, e a obra de Eugene O'Neill, ele comenta: "Se O'Neill denominou sua trilogia, inspirada na Orestíada, Mourning Becomes Electra ( $O$ Luto Transforma-se em Electra, O Luto Assenta em Electra, Electra Enlutada ou Electra e os Fantasmas, dependendo da criatividade do tradutor brasileiro), poder-se-ia chamar a peça nacional (com perdão pela idéia de não muito bom gosto): Electra Desintegrada."

Nos últimos tempos, Eudinyr estava envolvido em um projeto abrangente: um dicionário do teatro brasileiro, coordenado por João Roberto Faria. Chegou a escrever mais de trinta verbetes, e a parte que lhe cabia era a mais adiantada de todas. $\mathrm{O}$ projeto continua em andamento, mesmo sem ele. É João Roberto quem define o Eudinyr escritor: "Como autor, uma característica marcante de Eudinyr era ter, em primeiro lugar, o domínio do conceito com o qual decidira trabalhar, e depois a capacidade de mostrar, na análise das obras, como o conceito se sustentava. Assim, quando ele leu Qorpo-Santo e achou que havia ali mais elementos ligados ao Surrealismo do que ao Teatro do Absurdo, ele foi estudar profundamente a escola surrealista para confirmar essa primeira impressão. Na obra seguinte, ele procurou primeiro entender o Simbolismo em geral, depois o teatro simbolista, e então analisou o que existia realmente, em termos de traços simbolistas, naqueles autores específicos, alguns dos quais ele mesmo (re)descobriu. Sobre seu último livro, só posso dizer que é a melhor análise de Nelson Rodrigues como autor expressionista que eu conheço."

Formado no curso de Dramaturgia da Escola de Arte Dramática em 1963, Eudinyr escreveu várias peças, como Os carescentes e $A s$ Regras do Jogo; a primeira a ser montada foi $\mathrm{Ca}$ minhos de Deus, encenada na própria EAD por Alfredo Mesquita. O Departamento de Artes Cênicas da ECA, onde foi professor por tantos anos, também chegou a montar um texto seu: A Verdade dos Dias. Segundo Elisaberth Azevedo: "A peça gira em torno de uma senhora e de um jovem estudante de medicina que aluga um quarto na casa dela. Os dois falam dos sonhos desse jovem, de quem a mulher gosta como se fosse seu filho, até que ele desiste do curso e vai se casar com a filha de um fazendeiro rico, abandonando tudo o que pretendera até então. É uma peça sobre ideais e ilusões, sobre o que se planeja para a vida e que traz depois desilusão. É um texto profundamente melancólico, mas sem melodrama. Até nesse caso Eudinyr sabia fazer uso da ironia."

Sábato Magaldi, mesmo salientando que Eudinyr "não se realizou plenamente como dramaturgo", ressalta: "Eudinyr não fazia o óbvio, não se ajustava ao tipo de dramaturgia corrente. Seus textos eram mais de vanguarda, ele buscava uma coisa mais insólita."

A obra de ficção deixada por Eudinyr não se resume a textos teatrais; ele também produziu vários contos (alguns até publicados). Além dos dotes literários, tinha outro grande talento: era exímio pianista, a ponto de ter pensado em seguir carreira como concertista na juventude. Chegou a musicar versos, que o irmão cantava. $\mathrm{O}$ amor de Eudinyr pela música manteve-se durante toda a vida. Era um entusiasta da ópera, 
de tal forma que todos os anos, entre janeiro e fevereiro, viajava para conferir espetáculos no exterior. Ao morrer, já tinha comprado todos os ingressos da viagem seguinte, e contava poder embarcar na data prevista.

Como, enfim, definir Eudinyr Fraga? Seja como professor, autor, orientador ou pesquisador, sempre desempenhou suas facetas com entusiasmo e rigor. Na opinião de João Roberto Faria, foi como amigo que ele mais expressou sua personalidade ímpar: "Eudinyr era sempre muito amável e educado. Além disso, era um amigo extremamente leal em todos os momentos. Uma qualidade muito particular dele era a ironia, a mordacidade adorável, que era perceptível também naquilo que ele escrevia. Se havia algum espaço para o comentário, ele não perdia a piada, o que dá a seu texto um sabor todo especial..." Sábato Magaldi destaca outra virtude do saudoso amigo: "Para mim, a característica mais marcante do Eudinyr é que ele acreditava e se empenhava a fundo nas coisas. Ele nunca foi superficial, um vigarista, alguém que tapeia com lantejoulas para impressionar. Ele estudou profundamente tudo o que lecionou. Além disso, era um ótimo amigo, sincero e disponível. Tínhamos enorme respeito e carinho um pelo outro." Elisabeth Azevedo pontua, ainda, um terceiro aspecto: "Ele respeitava muito as idéias dos outros. Não abria mão de suas posições, mas ao mesmo tempo nunca criava atritos. E na forma de escrever e em seus comentários, era perceptível uma ironia em relação à vida, às pequenas vaidades das pessoas."

Diante dessas recordações, recolhidas entre outros companheiros e amigos de Eudinyr Fraga, convenço-me, enfim, que não sou a única a sentir a orfandade causada pela sua perda. 